\title{
Evaluation of sustainability of conventional agroecosystems and introduction of ecological farming systems in the Zagros region, Iran: a necessity towards sustainable rural development
}

\author{
M. Nael ${ }^{1} \&$ S. H. Matinkhah ${ }^{2}$ \\ ${ }^{1}$ Department of Soil Science, Bu-Ali Sina University, Hamedan, Iran \\ ${ }^{2}$ Department of Natural Resources, Isfahan University of Technology, \\ Isfahan, Iran
}

\begin{abstract}
Urban development is inconceivable without rural development. In sustainable rural development, agroecosystems are considered as self-sufficient systems, which should imitate and follow laws of nature. Quite the contrary, deforestation, overgrazing, conversion of rangelands to dryland farming and conventional managements of irrigated farmlands, such as monoculture, heavy tillage, unsound use of chemicals and fertilizers, are widespread and humanity and environment are suffering from them. Now, the only thing that prevents new villagers of Kurdistan to accept and practice these unsound managements is knowledge. First, to understand concretely the consequences that conventional managements have on the quality and health of their lands and crops; second, to have sufficient knowledge about the alternative, sustainable agricultural practices. Accordingly, the main goal of this study is to increase this twin awareness in the Koya region. This will be done firstly through, the evaluation and comparison of sustainability of current agroecosystems via a soil quality approach, and secondly, by introducing sustainable agroforestry systems via characterization of the existing practices in the study area, and by referring to the agroforestry systems which previously characterized the Zagros region of Iran. Thus, the objectives of this study are fourfold: 1 . Characterizing and registering the situation of conventional agricultural practices and customs of the Koya region. At this stage, all aspects of current agricultural management, land
\end{abstract}


ownership, technology and labor level, yield, etc. are studied and registered for major farmlands. Then, a preliminary classification of conventional management systems is established. According to this classification, a few important agroecosystems are selected for the second stage; 2 . Assessing soil health state in conventional agroecosystems of the region and determining the relative sustainability of the studied systems. In this stage, biological, chemical and physical indicators of soil quality are evaluated. In addition, in order to have sufficient knowledge about the inherent soil quality of selected farms, routine soil profile description and analysis will be performed; 3. Characterizing traditional ecological farming systems, including agroforestry and silvopastural systems, to design and extend sustainable agriculture. Important agroforestry systems will be found in the region, and their properties will be characterized. Three sources of data will be considered: registered criteria of the system, interviews with land users and primary ecological data. Then it will be necessary to classify the systems. Four classification bases may be employed for classification of the diagnosed systems; first, based on "the nature of components", then "ecological properties", "applied technology" and finally "socio-economic criteria". This stage is conducted parallel to the first stage; and 4. Introduction of ecological and sustainable farming systems based on stages 1 to 3, as well as on similar experiences obtained from case studies in Iran.

Keywords: sustainable rural development, soil health, indigenous knowledge, agroforestry.

\section{Introduction}

\subsection{Necessity of the study}

"Without vision the people perish". So wrote the poet William Blake. Urban development is inconceivable without rural development. One could even declare that the latter is more crucial and vital than the former because humanity cannot survive without food but can survive without industry. In sustainable rural development, agroecosystems are considered as self-sufficient systems, independent from inputs produced by industry. The more our farming systems are in conformity with the laws' of nature, the more are sustainable, healthy and permanent. Consequently, healthy food and healthy people are guaranteed. On this base, humanity is able to strive towards the loftiest goals.

Past political situation of Kurdistan has resulted to emigration of villagers and abandonment of countryside for a few decades. This period has been long enough to prevent the invasion of destructive farming practices, prevailing in most of the developing countries. As a result, the natural resources of Kurdistan has been preserved to a large extend, compared to the geographically similar areas, for example in Iran. Now that the political situation is stable and the government thinks about the rural development, it is logical and vital not to repeat the destructive experiences of other countries.

Deforestation, overgrazing, conversion of rangelands to dryland farming and conventional managements of irrigated farmlands, such as monoculture, heavy 
tillage, unsound use of chemicals and fertilizers, are widespread and humanity and environment are suffering from them. Now, the only thing that prevents new villagers of Kurdistan to accept and practice these unsound managements is knowledge. Firstly, to concretely understand the consequences that conventional managements have on the quality and health of their lands and crops; Secondly, to have sufficient knowledge about the alternative, sustainable agricultural practices.

Soil can be envisaged from a particular point of view as a passive substance that preserves and demonstrates the effects of past and current agricultural practices. In particular, soil quality assessment was developed in order to evaluate the relative sustainability of different farming practices. Soil quality is defined as "the capacity of the soil to function, within the ecosystem and landuse boundaries, to sustain biological productivity, maintain environmental quality, and promote plant and animal health"; therefore, it is one of the most important factors in developing sustainable land management and sustaining global biosphere (Wang and Gong [1] and Doran and Parkin [2]). If ecosystem processes are well understood, the sustainability of the system can be evaluated. Under such circumstances, soil quality assessment requires measuring the current state of an indicator and comparing the results to known or desired values (Karlen et al. [3]). Manley et al. [4] applied this methodology to evaluate sustainability of different rangeland management systems by the response of $\mathrm{C}$ and $\mathrm{N}$ to grazing. Soil organic matter, soil porosity, and infiltration rate have been recently proposed as major soil quality indicators in forest soils by international groups (Doran et al. [5] and Elliot et al. [6]). Further, there is a growing interest in using soil microbial parameters as indicators of soil quality changes after revegetation of disturbed soils (An et al. [7]). Enzyme activities play key roles in the biochemical functioning of soils, including soil organic matter formation and degradation and nutrient cycling (Acosta-Martínez et al. [8]). It has been reported that any change in soil management and land use is reflected in the soil enzyme activities, and that they can anticipate changes in soil quality before they are detected by other soil analyses (Ndiaye et al. [9]).

Agroforestry is an integrated approach of using the interactive benefits from combining trees and shrubs with crops and/or livestock. It combines agricultural and forestry technologies to create more diverse, productive, profitable, healthy, and sustainable land-use systems. Hundreds year experiences of farmers formed precious indigenous knowledge of Agroforestry, which is going to be lost soon by modern life. Characterization of agroforestry means to study these existing practices to find the best solutions and methods of integrating woody perennial plants with the fragile land use systems in accordance to the local conditions.

The objectives of this study are fourfold:

1. Characterizing and registering the situation of conventional agricultural practices and costumes of Koya region.

2. Assessing soil health state in conventional agroecosystems of the region and determining the relative sustainability of the studied systems. 
3. Characterizing traditional ecological farming systems, including agroforestry and silvopastural systems, to design and extend sustainable agriculture.

4. Introduction of ecological and sustainable farming systems, with the emphasis on agroforestry systems, based on stages 1 to 3 , as well as on similar experiences obtained from case studies in Iran.

\section{Literature review}

\subsection{Soil health}

To introduce some soil quality indicators potentially sensitive to land degradation in selected semiarid rangelands and farmlands of central Iran, as well as to determine the relative sustainability of different land managements of the region, the authors conducted the two following studies:

1. A four-year investigation (1999-2002) was conducted to understand the changes of soil functions caused by different rangeland management systems in protected research pasture of Hamzavi Station, Semirom, Isfahan. In 1999, two sites, a reserved and a disturbed pasture, were analyzed for organic carbon (OC), total nitrogen (TN), microbial respiration (MR), aggregate mean weight diameter (MWD), and infiltration rate (IR) of the surface soil. In 2002, a third land use, a controlled (every four year) grazing management system, was added to the previous sites; and in addition to OC, MR, and TN, phosphatase activity (PA), saturated hydraulic conductivity (Ks), bulk density (BD) and the ratio of water dispersible clay to total clay $\left(\mathrm{Cl}_{\mathrm{WD}} / \mathrm{Cl}_{\mathrm{T}}\right)$ of the three sites were measured.

\subsection{Results and discussion}

Selected properties of surface soil and estimated cover of different sites are presented in Table 1. Soil texture of the three sites are quite similar, however, the equivalent carbonate content of the disturbed site is significantly higher than PR

Table 1: $\quad$ Selected properties of surface soil $(0-15 \mathrm{~cm})$ and estimated cover of different ecosystems, in 1999.

\begin{tabular}{ccccc}
\hline $\begin{array}{c}\text { Land } \\
\text { use }\end{array}$ & $\mathrm{pH}$ & $\begin{array}{c}\mathrm{CaCO}_{3} \\
(\%)\end{array}$ & Texture & $\begin{array}{c}\text { Cover } \\
(\%)\end{array}$ \\
\hline $\mathrm{PR}$ & $7.8^{\mathrm{a}}$ & $14.2^{\mathrm{b}}$ & silty clay loam & 38 \\
$\mathrm{DR}$ & $8.0^{\mathrm{a}}$ & $23.0^{\mathrm{a}}$ & silty clay loam & 5 \\
$\mathrm{CR}$ & $7.8^{\mathrm{a}}$ & $16.0^{\mathrm{b}}$ & silty clay loam & 35 \\
\hline
\end{tabular}

PR, DR, and CR: protected, disturbed, and controlled-grazing rangeland, respectively

Different letters in each column indicate $\mathrm{P}<0.05$. 
and CR sites, showing the partial exposure of carbonate-rich subsurface horizon due to water sheet erosion and cultivation in DR site. The summary statistics of the soil quality indicators are given in Tables 2, 3 and 4. In 1999, organic carbon and microbial respiration were significantly higher in the protected site than in disturbed area $(\mathrm{p}<0.001)$. No significant difference was observed between two sites for total nitrogen and infiltration rate $(\mathrm{p}<0.05)$. In contrast, the mean diameter of water stable aggregates was higher in disturbed site $(p<0.001)$ (Table 2).

Table 2: $\quad$ Statistical comparisons of selected soil quality indices in two ecosystems studied in 1999.

\begin{tabular}{cccccc}
\hline Land use & $\begin{array}{c}\mathrm{OC} \\
(\%)\end{array}$ & $\begin{array}{c}\text { MR } \\
(\mathrm{mg} \\
\left.\mathrm{CO}_{2} / \mathrm{g} . \mathrm{day}\right)\end{array}$ & $\begin{array}{c}\mathrm{TN} \\
(\%)\end{array}$ & $\begin{array}{c}\text { MWD } \\
(\mathrm{mm})\end{array}$ & $\begin{array}{c}\text { IR } \\
(\mathrm{mm} / \mathrm{min})\end{array}$ \\
\hline PR & $0.72^{\mathrm{a}}$ & $0.23^{\mathrm{a}}$ & $0.1^{\mathrm{a}}$ & $0.35^{\mathrm{b}}$ & $0.23^{\mathrm{a}}$ \\
DR & $0.45^{\mathrm{b}}$ & $0.14^{\mathrm{b}}$ & $0.08^{\mathrm{a}}$ & $0.39^{\mathrm{a}}$ & $0.25^{\mathrm{a}}$ \\
\hline
\end{tabular}

PR and DR: protected and disturbed rangeland, respectively

Different letters in each column indicate $\mathrm{P}<0.05$.

The parameters OC, MR, and MWD were significantly higher in samples taken under vegetation as compared to the barren spaces between plant species in the protected rangeland. In disturbed rangeland, because of complete removal of vegetation and subsequent tillage, all samples were taken from the barren spaces (Table 3).

Table 3: $\quad$ Ratio of the mean soil quality indices measured under vegetation to that between vegetation in 1999 .

\begin{tabular}{cccc}
\hline $\begin{array}{c}\text { Land } \\
\text { Use }\end{array}$ & $\begin{array}{c}\mathrm{OC} \\
(\%)\end{array}$ & $\begin{array}{c}\mathrm{MR} \\
(\mathrm{mg} \\
\left.\mathrm{CO}_{2} / \text { g.day }\right)\end{array}$ & $\begin{array}{c}\text { MWD } \\
(\mathrm{mm})\end{array}$ \\
\hline $\mathrm{PR}$ & $1.56^{* * *}$ & $1.75^{* * *}$ & $1.2^{*}$ \\
$\mathrm{DR}$ & $\mathrm{NA}$ & $\mathrm{NA}$ & $\mathrm{NA}$ \\
\hline
\end{tabular}

PR and DR: protected and disturbed rangeland, respectively

NA indicates not applicable.* indicates $\mathrm{P}<0.05$; *** indicates $\mathrm{P}<0.001$.

The content of OC and MR has increased due to the grazing exclusion in rangeland region; but this management has not affected $\mathrm{TN}$, mainly because of the application of $\mathrm{N}$ fertilizers in cultivated, disturbed site. Since the application of manure is not a usual practice in the region, its contribution to soil OC content is negligible. Insignificant difference in hydraulic condition of the two sites could be explained by the fact that infiltration rate is an indicator of historic 
disturbance regime. In other words, reestablishment of the rangeland has not influenced long-term soil quality indicators. Nonetheless, it is notable that initial infiltration rate in disturbed site $(2.2 \mathrm{~mm} / \mathrm{min})$ was slightly higher than that in protected site $(1.8 \mathrm{~mm} / \mathrm{min})$ because of destruction of the surface seal caused by grazing and cultivation. Soil crust destruction would result in rapid initial infiltration rate, but it has no effect on final infiltration rate. Therefore, complete grazing exclusion has encouraged the process of crust formation in intershrub spaces; this explains the significant decrease of aggregate stability of barren soil (Table 3) in protected site compared with disturbed one (Table 2). Parallel investigations on growth condition of dominant species of the region showed that the maximum growth of Erotia ceratoides is maintained under controlled grazing management, where crust formation is inhibited, not in complete grazing exclusion (Khademi [10]).

Statistical comparisons of selected soil quality indices in three sites studied in 2002 are given in Table 4. Among physical indices, only BD showed to be sensitive to different management practices. Disruption of the soil surface due to overgrazing followed by cultivation in the disturbed site has culminated in a significant decrease of BD compared to the other sites. OC and PA tend to be highest in reserved rangeland and lowest in disturbed rangeland. Phosphatase is an extracellular enzyme, produced mainly by microorganisms, plant roots and worms, has a close relation with soil OC, soil moisture and rhizosphere volume. As for MR and TN, the highest values were observed in reserved rangeland and the lowest values in disturbed as well as controlled-grazing rangeland.

Table 4: $\quad$ Statistical comparisons of selected soil quality indices in three sites studied in 2002.

\begin{tabular}{cccccccc}
\hline $\begin{array}{c}\text { Land } \\
\text { use }\end{array}$ & $\begin{array}{c}\mathrm{OC} \\
(\%)\end{array}$ & $\begin{array}{c}\mathrm{MR} \\
(\mathrm{mg} \\
\left.\mathrm{CO}_{2} / \mathrm{g} . \mathrm{day}\right)\end{array}$ & $\begin{array}{c}\mathrm{PA} \\
(\mu \mathrm{mol} \\
\text { PNP/g.hr })\end{array}$ & $\begin{array}{c}\mathrm{TN} \\
(\%)\end{array}$ & $\mathrm{Cl}_{\mathrm{WD}} / \mathrm{Cl}_{\mathrm{T}}$ & $\begin{array}{c}\mathrm{BD} \\
\left(\mathrm{g} / \mathrm{cm}^{3}\right)\end{array}$ & $\begin{array}{c}\mathrm{Ks} \\
(\mathrm{cm} / \mathrm{min})\end{array}$ \\
\hline $\mathrm{PR}$ & $0.74^{\mathrm{a}}$ & $0.27^{\mathrm{a}}$ & $1.68^{\mathrm{a}}$ & $0.08^{\mathrm{a}}$ & $0.25^{\mathrm{a}}$ & $0.90^{\mathrm{ab}}$ & $5.4^{\mathrm{a}}$ \\
$\mathrm{DR}$ & $0.59^{\mathrm{b}}$ & $0.16^{\mathrm{b}}$ & $0.70^{\mathrm{c}}$ & $0.06^{\mathrm{b}}$ & $0.26^{\mathrm{a}}$ & $0.87^{\mathrm{b}}$ & $5.3^{\mathrm{a}}$ \\
$\mathrm{CR}$ & $0.64^{\mathrm{ab}}$ & $0.16^{\mathrm{b}}$ & $1.35^{\mathrm{b}}$ & $0.06^{\mathrm{b}}$ & $0.29^{\mathrm{a}}$ & $0.94^{\mathrm{a}}$ & $5.1^{\mathrm{a}}$ \\
\hline
\end{tabular}

PR, DR, and CR: protected, disturbed, and controlled-grazing rangeland, respectively. Different letters in each column indicate $\mathrm{P}<0.05$.

Among the selected soil attributes in the studied rangeland, PA, OC, MWD, and $\mathrm{BD}$ are the most reliable indicators of soil quality. Microbial Respiration can only discriminate between extreme managements, but is not sensitive to small soil disturbances. Infiltration rate could not reveal short-term changes of soil functioning. Total nitrogen, as a soil quality indicator, is misleading because of human practices, which may confound the results. The first phase of this study revealed that complete grazing exclusion has improved some fundamental 
aspects of soil quality, but has culminated in crust formation in this management. Although in this step, it was suggested that controlled grazing management will probably meet the ideal soil functioning, the second phase of the study did not support the idea.

2. The effect of conventional management systems on soil quality indices in Boroojen, Charmahal Bakhtiyari, was assessed in order to identify the most sustainable practices. Five management systems including a protected rangeland, an overgrazed rangeland, an abandoned dryland farm, an irrigated wheat farm and an alfalfa farm were selected. Organic matter (OM), PA, MR, TN, Ks and $\mathrm{BD}$ were measured in the surface soil samples of each site. PA and OM were maximum in alfalfa farm and minimum in both abandoned dryland farm and overgrazed rangeland. The highest rate of MR and TN content were obtained for alfalfa and wheat farms. The lowest potential of MR was measured in protected and overgrazed rangeland, while the lowest amount of TN was determined in overgrazed rangeland and abandoned dryland farm (Khademi et al. [11]; Mohammadi et al. [12]).

Studies with the same objectives are going on by the authors in Hamedan. For instance, the sustainability of different cover plants and conservational tillage practices in irrigated farmlands of the Bahar region, as well as different grazing managements of Gonbad region are under evaluation.

\subsection{Agroforestry}

During our previous studies on traditional agroforestry systems in Iran, we have invented an inventory method to characterize them. The subsequent framework was refined according to an iterative process involving characterizing of the systems, obtaining the needed information for each criterion by a diagnostic team, comparing the systems to each other, and finally reviewing through the elements of the framework. This constitutes 15 basic characters; some of them contains sub-elements (Matinkhah [13]; Matinkhah et al. [14]). The same study process can be used to achieve a suitable framework for Kurdistan's systems.

\section{Proposed materials and methods}

In line with the four objectives, present study is conducted in four phases:

1. Through interview with local authorities and farmers, and field observations, the main and widespread agricultural management units of Koya region are characterized and registered. In this stage, all aspects of current agricultural managements, including, land ownership, technology and labor level, yield, etc. are studied and registered. Finally, a classification of current agroecosystems is established. According to this classification, a few important agroecosystems are selected for the second stage.

2. The condition of soil health in selected agroecosystems is determined through a soil quality approach. For this, soil samples with enough replications are taken from plough layer and physical, chemical and biological indicators of 
soil quality, such as organic carbon, active organic carbon, phosphatase activity, aggregate stability, bulk density, microbial activity, induced microbial activity, infiltration rate, total nitrogen, available $\mathrm{K}$ and $\mathrm{P}$, are measured. In addition, in order to have a sufficient knowledge about the inherent soil quality of selected farms, routine soil profile description and analysis will be performed.

3. and 4. In tours to be conducted throughout the study area, important agroforestry systems will be found, and their properties will be characterized. Three sources of data will be considered: registered criteria of the system, interviews with land users and primary ecological data. Then it will be necessary to classify the systems. Four classification bases may be employed for classification of the diagnosed systems; first based on "the nature of components", then "ecological properties”, “applied technology" and finally "socio-economic criteria". So in the primary studying phase three steps are considered, first developing a method for characterizing and then applying the method for the important agroforestry practices and lastly comparing the results of both countries. Based on the results, sustainable agroforestry systems can be designed and finally can be extended to the farmers.

\section{Conclusion}

Our first study showed that complete grazing exclusion of the rangeland has resulted in higher OC and MR with no effect on the amount of TN and IR. The apparently negative effect of this management system was a decrease in aggregate stability due to crust formation in bare surfaces between plant patches. However, MWD was significantly higher in samples taken under vegetation as compared to bare soil. The results of the second phase of this study, in 2002, revealed that among physical indices, only $\mathrm{BD}$ is sensitive to different management practices. Disruption of the soil surface due to overgrazing followed by cultivation in the disturbed site has culminated in a significant decrease of BD compared to the other sites. OC and PA tend to be highest in reserved rangeland and lowest in disturbed rangeland. As for MR and TN, the highest values were observed in reserved rangeland and the lowest values in disturbed as well as controlled-grazing rangeland. Although it was suggested earlier that controlled grazing management may improve soil quality attributes compared to complete grazing exclusion, but our research did not support it, at least as far as selected biological indices are concerned (Nael et al. $[15,16])$.

The findings of our second study indicate that continuous wheat cultivation, as the most prevalent agroecosystem in the region, decreases soil quality. This study also shows that abandoned dryland farming is ecologically the least sustainable land use. Besides, soil phosphatase activity, organic matter content and hydraulic conductivity seem to be the most reliable soil quality indices for the area (Khademi et al. [11]; Mohammadi et al. [12]).

In Zagros region, certain similarities exist between Iran and Kurdistan with respect to environmental conditions. As characterized by Zohary [17], the Kurdo-Zagrosian steppe-forest consists mainly of deciduous, broad-leaved trees or shrubs with a dense ground cover of steppe vegetation. Nearly 100 million 
hectares (70 percent) of the lands in Iran are subject to desertification (United Nations Report [18]). This is what should be anticipated in Kurdistan with a better evaluation of sustainability of conventional agroecosystems. What is presented in this paper is a brief suggestive investigational approach to some solutions for sustainable rural development.

\section{References}

[1] Wang, X. and Gong, Z., (1998). Assessment and analysis of soil quality changes after eleven years of reclamation in subtropical China. Geoderma, 81, 339-355.

[2] Doran, J. W. and Parkin, T. B., (1994). Defining and assessing soil quality. In Defining Soil Quality for a Sustainable Environment (pp. 3-21). Soil Sci. Soc. Am. Special Publication, No. 35, Madison, Wisconsin.

[3] Karlen, D. L., Mausback, M. J., Doran, J. W., Cline, R. G., Harris, R. F., Schuman, G. E., (1997). Soil quality: a concept, definition and framework for evaluation. Soil Sci. Soc. Am. J., 61, 4-10.

[4] Manley, J. T., Schuman, G. E., Reeder, J. D., Hart, R. H., (1995). Rangeland soil carbon and nitrogen responses to grazing. J. Soil Water Conserv. 50, 294-298.

[5] Doran, J. W., Leibig, M., Santana, D. P., (1996). Soil health and sustainability. Adv. Agron., 56, 1-56.

[6] Elliot, W. J., Page-Dumroeses, D., Robichaud, R., (1999). The effect of forest management on erosion and soil productivity. In Soil Quality and Soil Erosion (pp. 195-208). Soil and Water Conservation Society and CRC Press, Boca Raton.

[7] An, S. S., Huang, Y. M., Zheng, F. L., (2009). Evaluation of soil microbial indices along a revegetation chronosequence in grassland soils on the Loess Plateau, Northwest China. Applied Soil Ecology, 41, 286-292.

[8] Acosta-Martínez, V., Cruz, L., Sotomayor-Ramírez, D., Pérez-Alegría, L., (2007). Enzyme activities as affected by soil properties and land use in a tropical watershed. Applied Soil Ecology, 35, 35-45.

[9] Ndiaye, E. L., Sandeno, J. M., McGrath, D., Dick, R. P., (2000). Integrative biological indicators for detecting change in soil quality. Am. J. Alter. Agric. 15, 26-36.

[10] Khademi, H., (1992). Soil survey report of Hamzavi Reserve Station, Hanna, Semirom. Jahade' Sazandegi, Isfahan (in Persian).

[11] Khademi, H., J. Mohammadi and M. Nael. 2006. Comparison of selected soil quality indicators in different land management systems in Boroojen, Chaharmahal Bakhtiari Province. The Scientific J. of Agriculture, Shahid Chamran University, 29(3): 111-125 (Abstract in English).

[12] Mohammadi, J., H. Khademi and M. Nael. 2005. Study the variability of soil quality in selected ecosystems of Central Zagros. J. of Science and Technology of Agriculture and Natural Resources, Isfahan University of Technology, 9(3): 105-120 (Abstract in English). 
[13] Matinkhah, S.H. 2003. Study of existing agroforestry systems and their improvement: A case study in Kohkiluye-Boyerahmad. Ph.D. Dissertation in Forestry, Tarbiat Modarres University.

[14] Matinkhah, S.H. 2004. Characterization of home gardens: A case study in Kohkiluye-va-Boyerahmad, Iran; 1st World Congress of Agroforestry Working Together for Sustainable Land-use Systems, Orlando, Florida USA.

[15] Nael, M., H. Khademi and M. A. Hajabbasi. 2004. Response of soil quality indicators and their spatial variability to land degradation in central Iran. J. Applied Soil Ecology, 21: 221-232.

[16] Nael, M., Khademi, H. and Mohammadi, J. 2012. Evaluation of soil degradation in different rangeland management systems via a soil quality approach in central Iran. International soil congress on "Land Degradation and Challenges in Sustainable Soil Management” cesme, Izmir, Turkey, May 15-17.

[17] Zohary, M. 1973. Geobotanical foundations of the Middle East. Gustav Fischer Verlag, Stuttgart, Germany.

[18] United Nations report, http://www.un.org/esa/sustdev/sdissues /desertification/beijing2008/presentations/rajabi.pdf 